뚱ำ

\title{
BUILDING CHILDREN'S CHARACTER THROUGH TRADITIONAL BALINESE GAME: MEGALA-GALAAN REVISITED
}

\author{
Ida Ayu Gde Yadnyawati \\ Faculty of Hindu Education and Arts \\ Universitas Hindu Indonesia \\ <dayuyadnya@yahoo.com>
}

\begin{abstract}
Character is the values of human behavior associated with God Almighty, self, fellow human, environment, and nationality embodied in thoughts, attitudes, feelings, words, and deeds based on religious norms, law, etiquette, culture, and customs. Character education, according to Thomas Lickona (1991), is the education to shape the personality of a person through character education, whose results that can be seen in the actual actions of a person that are considered good, honest, responsible, respectful of the rights of others, hard work, and others. Building the character of children can be done through a traditional Balinese game called megala-galaan. This game is often played with accompaniment of singing Goak Maling Taluh. The poem Goak Maling Taluh sound simple with rhythm or easy rhythm, and the author was still anonymous until now. Behind the simplicity of his poetry hides a deep philosophical meaning about the nature of karma phala. The megala-galaan game with the singing Goak Maling Taluh implementation of fun learning concepts, a traditional Balinese educational concept that emphasizes aspects of learning while playing, and playing while learning.
\end{abstract}

Keywords: character, games, traditional Bali.

\section{Introduction}

Man is a connected being, connected with society, his

environment, himself, and God.

Beerling puts forward that Heinemann signals that in the 20th century humans experienced a total crisis, called such because the crisis hit not only certain aspects of life such as the economic crisis, energy crisis and so on, but also its own human beings. (Beerling, 1951: 43)

In a total crisis, Man experiences a crisis of relations with society, his environment, himself, and the Creator. This means that there is no careful 
introduction and understanding of what or who he is related to. This is the disaster that has plagued humankind such that people have drifted far away from happiness.

All of the above will not happen provided the educators have properly guided and provided purposeful instructions to their students. The aim of education is to help learners cultivate their human potential. The potential of humanity is the seed of possibility to become human. Mango seeds, for instance, if they are planted properly, must become a mango tree instead of a cashew tree.

Educational tasks are only possible with the right and proper purpose, if the educator has a clear picture of what the authentic human truly is. Humans possess characteristics that are principally different from animals. The distinctive features of humans that distinguish themselves from animals are made up of an integrated set of what is called human nature, called so because in essence it belongs only to humans and not possessed by animals (Tirtarahardja, 2015, 1).

This human nature needs to be understood by educators because it will form a map of human characteristics, which will provide a strong foundation in behaving, strategizing, creating methods and approaches used in interacting.

The true and clear picture of humanity is necessary for educators due to the rapid development of science and technology today, and increasingly more so in the future. Indeed many benefits that can be achieved for human life derive from human beings. On the other hand, what cannot be avoided will have a negative impact, which sometimes unknowingly can be very harmful and may even threaten the wholeness of human existence.

The nature of human nature is defined as characteristic traits that in principle distinguishes humans from animals. However, many similarities abound between humans and animals, especially when viewed in terms of the biological aspect.

Humans, walking vertically with the use of both legs, childbirth and breastfeeding their children, eaters of all, with the existence of metabolic equations regarding humans, led some philosophers such as Socrates to call humans the "Zoon Politicon" (Animals of the Community), while Max Scheller described humans as the ever restless "Das Kranke Tier" (a sick animal) (Drijarkara, 1962, 138).

Such facts and statements can lead to a false impression, assuming that animals and humans differ only gradually, a difference that by engineering can be made into the same state, such as water due to changes in temperature solidify into ice cubes. As if with engineering skills, by way of education, forest people can be made "human". Human effort to 
obtain information that animals are not identical to humans have been found.

Charles Darwin, with his theory of evolution, struggled but failed to prove that humans came from primates or apes. There is a mystery that is considered to bridge the process of change from primate to human that can not be disclosed called the missing link (or a broken link), that points to a process between the unexplainable. So far, no evidence has been found that shows that humans appear as a change of form from primates or apes through a gradual process of evolution (Tirtarahardja, 2015; 3).

The manifestation of the nature of man (that is not possessed by animals) is expressed by the notion of existentialism, with the intention of being the input in building character. They are:

1. Ability for Self-awareness

2. Ability to exist

3. Owning conscience

4. Moral

5. Responsibility

6. Sense of freedom (independence)

7. Willingness to perform obligations and realize rights

8. Ability to live happily.

By understanding the nature of human, it will be easy for the educator to assist in the development of character of learners.

Character is the values of human behavior associated with
God Almighty, self, fellow human, environment, and nationality embodied in thoughts, attitudes, feelings, words, and deeds based on religious norms, law, etiquette, culture, and customs. Character education, according to Thomas Lickona (1991), is the education to shape the personality of a person, whereby results are seen in the actual actions of the person in the form of good behavior, honesty, being responsible, having respect for the rights of others, being hard working, and others.

The definition of character education is further elucidated by Elkind and Sweet (2004). "Character education is the deliberate effort to help people understand, care about, and act upon core ethical values. When we think about the kinds of character we want for our children, it is clear that we want them to be able to judge what is right, care deeply about what is right, and then do what they believe to be right, even in the face of pressure from without and temptation from within."

The process of moulding the character of children can be done through a traditional Balinese game Megala-galaan. This game is often played with the accompaniment of singing Goak Malingtaluh (The crow steals an egg). The poetic song goak malingtaluh sounds simple with an easy rhythm, created anonymously. Behind the simplicity of his poetry implies and expresses a deep philosophical meaning 
of the nature of Karma Phala. In this context, Cheng Yishu's words ring true: there is truth in things when we examine them carefully. To build the character of the child can be done through the traditional Balinese game megalagalaan.

\section{Discussion}

\section{The Character}

Since the government has enacted character education nationally at all levels of education, character education has become a hot issue in the field of education, be it scientific forums, such as seminars, workshops, training, discussions, etc. organized by various groups involving experts from various disciplines, especially Education experts (AgusWibowo, 2013, 33).

According to Dani Setiawan (2010) the root of this character is derived from the Latin word "kharakassein" and "kharax" meaning tools for marking, to engrave, and "pointed stake." This word began to be widely used in French as "caractere" in the 14th century, and when entered into English, the word "caractere" is transformed into "character". In Indonesian, the latin spelling "karakter" became character. According to Suyanto (2010), character is the way of thinking and behaving that characterizes each individual to live and work together, both within the scope of family, community, nation and state. As for individuals who are of good characters, are individuals who can make decisions, and are ready be accountable for what they do, or dare to be responsible for every consequence of the decisions made (Agus Wibowo, 2013, 26)

Based on the opinion as described can be concluded that the character is a characteristic of individuals that include attitudes, behaviors, motivations, and skills, morals, or personality formed from the results of internalization of various policies (virtues) that are believed and used as a basis for one's worldview, thinking, attitude, and actions.

Factors Affecting Individual Behavior

Many factors - internal or external - influence the behavior of individuals. Internal factors are all the properties and skills possessed or controlled by individuals in development, obtained from the offspring or because of interaction descent with the environment. External factors are all things that individuals receive from their environment.

\section{a. Heredity}

Heredity are all characteristics, traits, potentials and abilities possessed by the individual by birth. These characteristics, attributes and abilities are brought by the individual from his birth, and are accepted as descendants of both parents. There are two categories of traits possessed by the individual, namely permanent characteristics and traits. Sedentary traits are seen as innate or hereditary, 
such as skin color, hair, nose, eyes, ears, etc.

Abilities are often regarded as innate factors, thus being sedentary is intelligence or intelligence and talent. Intelligence is a common ability, while talent is a special ability such as talent in music, sports, economics, agriculture, mathematics, language, engineering, etc. Changing characteristics or traits are categorized as environmental factors or environmental factors influenced by the environment. Such characteristics or characteristics, eg body, attitude, habit, interests, perseverance, etc. (Sukmadinata, 2003; 44).

\section{b. Environmental Factor}

Behavior shown by the individual is not something done alone but always in its interaction with the environment. Likewise, the nature and abilities possessed by individuals are mostly obtained through their relationship with the environment. The environment is all the factors that affect the individual. Such an environment may be around individuals, may also be away from the individual, present, or long gone, the environment is effective or ineffective. The environment may consist of natural and geographical, economic, social, cultural, political, religious, security and so on.

The natural and geographic environment in which the individual lives affects the individual's development and behavior. A person born and raised in a mountainous area, will have the qualities and skills to live in the area. The natural condition of agricultural areas with relatively cool air will form healthy, strong, soft-spoked, talkative, and skilled individuals in agriculture (Sukmadinata, 2003 47)

Man is a social being, needs the company of other human beings, and his behavior shows the relationships with others. He will feel the silence when living alone; he will also feel homesick even when in a relationship with a loved one. Factors concerning the relationship of a human being to other human beings is called the social environment. The social environment always involves the relationship between a human being and another human being. The relationship can be between individuals, the individual with a groups, or between groups.

\section{c. Maturity Factor}

In addition to carriage and the environment there is one other important factor that also influence the individual development, namely the maturity factor. Although a child has a great character and is raised in a complete and good environment, but if something is not yet mature or ready to flourish, there will be no progress. After all, the genius is a child, just two years old is impossible to learn to read, write, count. (Sukmadinata, 2003: 51).

Child development period contains a series of maturity period. For each individual and every aspect of development, although there are 
common patterns that are almost uniform, there is also a variation of child A, for instance, who may be faster in talking, normal paced in teething, and slow in walking. Take another example, Child B, who is quick to talk and walk, but has slow growth of his teeth.

\section{The Balinese Traditional Games Megala-galaan}

The megala-galaan game is a team game that consists of two teams. Each team consists of three people. With hompipa (participant uses their palms to decide the winner) or syut (participant use their fingers to decide the winner) the winning team can start the game to become a home seeker. On the way home (usually there are three boxes that are considered houses) is blocked by an opposing squad that guards the line of every home area. If anyone is touched by the hand of the line guard then the person in the game box (the house) is declared dead and out of the arena. If the three people of the team can reach the hands of the box line by the line guards of the other squads then the team in the turn box becomes the line guard and the team that had kept the starting line of the game. If a team looking for a home can get past the line guard smoothly and get to the next home it will get a score. Whose team gets the most score until the end of the game then it will come out as the winner. It is fun that in every session, the game is always followed by the song Goak
Maling Taluh.(Adi Swartawan,2010;2)

In singing dolanan (traditional games song) Goak Maling Taluh usually done rotate from the team guard the line until the team is in the game box. The megala-galaan game with the chanting of goak maling is an implementation of the concept of fun learning, a traditional Balinese educational concept that emphasizes aspects of learning while playing and playing while learning. In this megala-galaan game, will be formed. The values embedded are: discipline, honesty, passion, togetherness, cooperation, solidarity, good-bad value.

How is the poetry and the meaning of a dolanan song Goak Maling Taluh? Let's look at the following description: The dolanan song goak malingtaluh that accompanies the game megalagalaan of Balinese children is sung as followed:

"guak maling taluh gedang renteng kayu lengkong; nyen uli bedauh natad meng ngadut meong"

(Rasta Made: Dolanan Bali blogsport. com2009/08/dolanan-bali.html)

The word goak means the black crow with the sound of the goats. Thus the naming of goak is according to the sound of the bird referred. In Bali, two types of goak are known: the flower of a small shape and size of the body with a small voice loud, and goak bangke with a big voice moody and creepy. The goak is a type of bird classified as a carnivore, which is a predator of other 
animals such as snakes, rats, chicks, ducks and other small birds. Typically, birds in Bali are considered to be an omen, such as a tetengger (hunch) that negative incidents will happen to a region, such as the outbreak of a disease, death and so forth.

The word goak in the song goak maling taluh implies someone who does not always do good in his life. One of the deeds of the birds in the above song refers to a thieving thief that freely steals eggs. The word "thief" clearly refers to a despicable act that is forbidden in the teachings of Hinduism. While the word taluh means egg, it can be interpreted as the seed of life called brahmananda. This is the life egg that will be stolen by the crow according to the meaning of the game above. The act of stealing the seeds of life is said to be a despicable act described in the symbolic words of the mutual barge. The word gedang (which means papaya), when combined with the word renteng, translates to the papaya that is merely a flowering chain but never bears fruits. Gedang renteng in Bali is believed as a place or means of black magic (or majik). Thus the act of stealing in this sense can be taken as a form of activity done by those who do not know the rules of religion or people who practice black magic.

The assertion that deviant behavior or breaking dharma as told in the song goak maling taluh is a misleading act. This action is analogized like lengkong wood which is freely translatable as bent wood. Wood in the meaning of means kayun (feeling) or desire of mind, while the word crook means not straight or not in accordance with the rules that is, the rules of truth. Thus lengkong wood means the mind of someone who deviates and does not comply with the instructions of religious teachings.

In a single sentence bird thief eggpapaya not straight wood parchment contains a story or an analogy of the actions of someone who is not moral, likening the behaviour to a crow that stole the eggs of life, or the behavior of black magicians whose minds are crooked and can not be straightened out. However, in the second verse it is emphasized that whatever one does in this world must be accounted for when he returns to nature. This emphasis is implied in the sentence nyen uli bedauh natad meng ngadut meong. A loose translation of this verse means: "who comes from the west carrying or pulling (natad) the cat and cutting (ngadut) cat."

Coming from the West also means walking east. The direction of the East in the context of Hindu teachings refers to the holy direction as a place where the sun rises, which is also called sunyaloka. Here, the direction of sunyaloka is a symbol of the direction directed by the 'spirit' after death arrives. If one goes eastward at the position of the sun still in the East, it will be followed by its shadow. Shadows can be analogized as a result 
of deeds. Thus someone who comes from the West is defined as a 'spirit' that runs towards sunyaloka after death arrives. The arrival of a person to the sunyalokapada his life followed by the results of acts committed during his lifetime. If he does no good, as symbolized by bringing a cat (natad and ngadut meng or meong), then all forms of bad deeds will continue to follow the journey of the spirit. It also means that one ultimately cannot be separated from what is called karma phala.

Both the bad deeds of a person as depicted in the song goak thief until the end will follow the final journey of 'The Spirit' to the sunyaloka or the 'next' realm. The description of the consequences of the act or karma phala is simply conveyed in a song through a game of mockery. If we associate with this game and listen for the meaning of the word gala, which means obstacles, then the mocking game gives an obstacle to someone to search for his home. This game with the song sung clearly implies that the ultimate goal of human life is to go home; the eternal home of all beings is God. The living being comes from God and will eventually return to God. This concept in Hinduism is called moksa. Thus, the mega-galaan game with the song goak maling taluh implicitly teaches two important parts of Panca Sradha (five beliefs of Hindus in their life: atma, paramatma, karmaphala, punarbhawa, moksa) namely Karmaphala (the law of karma) and Moksa (the absolute freedom).

\section{Conclusion}

Firstly, character is a characteristic of individuals that include attitudes, behaviors, motivations, and skills, morals, or personality formed from the results of internalization of various policies (virtues) that are believed and used as a basis for the worldview, thinking, attitude, and action.

Secondly, many internal and external factors influence the behaviors of individuals. Internal factors are all the properties and skills possessed or controlled by individuals in development, obtained from the descendants or as a result of interaction between the descendants and the environment. External factors are all the things that individuals receive from their environment.

Thirdly, the megala-galaan game is a team game that consists of two teams. Each team consists of three people. With hompipa or syut, the winning team can start the game to become a home seeker. On the way home (usually there are three boxes that are considered houses) is blocked by an opposing squad that guards the line of every home area. If anyone is touched by the hand of the line guard then the person in the game box (the house) is declared dead and out of the arena. If the three people of the team can reach the hands 
of the box line by the line guards of the other squads, then the team in the turn box becomes the line guard and the team that had kept the starting line of the game. If a team looking for a home can get past the line guard smoothly and get to the next home, it will get a score. The team that gains the highest score at the end of the game will become the winner. The fun is that in every session of the game, the song goak maling taluh follows.

Last, the megala-galaan game with the chanting of goak maling implements the concept of fun learning, a traditional Balinese educational concept that emphasizes aspects of learning while playing, and playing while learning. In this megala-galaan game, the values embedded are: discipline, honesty, passion, togetherness, cooperation, solidarity, the presence of the good-bad

value.[]

\section{References}

Anadas Ra. 2004. Hukum Karma. Surabaya: Paramita.

Jayaram. 2000. Memaknai Lagu Dolanan. Singaraja: Presspri.

Jendra Wayan. Karmaphala. Denpasar : Dewa Printing.

Sukmadinata, 2003, Landasan Psikologi; Bandung Remaja Rosdakarya

Tirtarahardja, 2015, Pengantar Pendidikan, Jakarta Rineka Cipta

Uno Hamzah, 2008, Perencanaan Pembelajaran, Jakarta; Bumi Aksara

Wibowo, 2013, Pendidikan Karakter, Yogyakarta; Pustaka Pelajar 